\title{
EFEK SIKAP WAJIB PAJAK, KESADARAN WAJIB PAJAK, PENGETAHUAN PERPAJAKAN TERHADAP KEPATUHAN PAJAK DI MASA COVID-19
}

\author{
Jeni Susyanti ${ }^{1)}$ dan Siti Aminah Anwar') \\ ${ }^{1,2}$ Jurusan Manajemen, Fakultas Ekonomi dan Bisnis,Universitas Islam Malang \\ ${ }^{1,2}$ Jl. MT Haryono 193, Malang, 65144 \\ E-mail : jenisusyanti@Unisma.ac.id ${ }^{1)}$,Saminaha.mlg4@gmail.com²)
}

\begin{abstract}
ABSTRAK
Pajak merupakan sumber pendapatan utama suatu negara yang memiliki peran penting dalam mendukung pembiayaan pembangunan dan menggambarkan kemandirian ekonomi. Tujuan dari penelitian ini adalah menganalisis faktor-faktor yang terdiri dari sikap wajib pajak, kesadaran wajib pajak, pengetahuan perpajakan yang mempengaruhi kepatuhan wajib pajak pelaku ekonomi kreatif individu millennial sub sektor fashion di Indonesia. Metode kuantitatif dengan menggunakan alat analisis Smart PLS (Partial Least Square), dengan teknik analisis pengujian data menggunakan statistik inferensial. Teknik pengumpulan data menggunakan kuesioner dengan unit analisis sub sektor fashion ekonomi kreatif. Hasil penelitian menunjukkan bahwa terdapat pengaruh langsung antara sikap wajib pajak, kesadaran wajib pajak, dan pengetahuan pajak terhadap kepatuhan pajak. Hal ini menunjukkan bahwa peningkatan sikap wajib pajak, kesadaran wajib pajak dan pengetahuan perpajakan dapat menyebabkan kenaikan kepatuhan pajak. Walaupun penelitian ini berhasil membuktikan pengaruh antar variabel, namun data sekunder selama covid-19 menunjukkan bahwa masih banyak pelaku ekonomi kreatif yang masih kebingungan dalam menerapkan peraturan perpajakan PMK no.86 / PMK.03 / 2020.
\end{abstract}

Kata Kunci: Kepatuhan Pajak, Sikap, Pengetahuan, Kesadaran Wajib Pajak, covid-19

\section{PENDAHULUAN}

Pajak adalah sumber pendapatan utama bagi sebuah negara, demikian juga di Indonesia. Pemerintah menetapkan target penagihan pajak yang sebesar $83,5 \%$ dari APBN pada 2020 membuat pemerintah Indonesia membuat berbagai peraturan perpajakan yang akan berpengaruh positif dan negatif ke beberapa sektor ekonomi, termasuk pada ekonomi kreatif. Banyak kendala yang terjadi pada tahun 2020 selain pandemi COVID-19, kendala yang dapat menghambat keefektifan pengumpulan pajak adalah kepatuhan wajib pajak (tax compliance). Sikap terhadap perilaku, norma subjektif sehubungan dengan perilaku, dan kontrol perilaku yang di persesuian biasanya digunakan untuk memprediksi niat perilaku dengan tingkat akurasi yang tinggi, tiga faktor penentu dari niat berperilaku yaitu: behavioural beliefs, normative beliefs, control beliefs berdasar Theory of Planned Behaviour Ajzen (Ghozali, 2020).

Ada beberapa faktor yang mempengaruhi kepatuhan pajak termasuk kelompok rujukan, probabilitas audit, pengetahuan pajak, dan persepsi pemerataan dan keadilan (Inasius, 2019), sikap wajib pajak (Lestari, 2017; Wijaya, 2019; Yustikasari, 2019), pendidikan pajak (Aladejebi, 2018; Kwok \& Yip, 2018), kurangnya pengetahuan yang memadai (Manual \& Xin, 2016; Newman et al., 2018; Susyanti \& Askandar, 2019).

Program Pemulihan Ekonomi Nasional (PEN) yang dilakukan pemerintah Indonesia untuk UMKM antara lain penundaan dan subsidi bunga bagi UMKM, hibah modal kerja, pelatihan menggunakan sarana daring untuk UMKM, pembuatan platform digital untuk pemasaran usaha. Selain program-program tersebut, guna meringankan beban PPh final bagi UMKM melalui PMK no.86/PMK.03/2020, penghapusan PMK no 44/PMK.03/2020, aturan ini merupakan perubahan atas PMK No 23/PMK.03/2020 tentang insentif pajak untuk wajib pajak yang terkena dampak wabah virus corona. Khusus bagi UMKM dapat memanfaatkan insentif bebas $\mathrm{PPh}$ final karena $0,5 \%$ tarif $\mathrm{PPh}$ final ditanggung oleh pemerintah mulai bulan April 2020 sampai dengan September dan diubah/dihapus dengan PMK no.86/PMK.03/2020 dengan PPh final ditanggung pemerintah sampai bulan Desember 2020.

Sikap merupakan sebuah evaluasi kepercayaan atas perasaan positif maupun negatif dari seseorang jika harus melakukan perilaku yang akan ditentukan (Sani, 2018). Sikap wajib pajak merupakan pertimbangan wajib pajak atas untung ruginya dalam memenuhi kewajiban pajaknya, pertimbangan terhadap kondisi keuangan untuk memenuhi kewajiban perpajakan dan risiko yang akan timbul akibat tidak membayar pajak.

Bahwa sikap, kesadaran, dan pengetahuan memiliki pengaruh secara signifikan terhadap kepatuhan wajib pajak, baik secara parsial maupun secara simultan (Mintje, 2016). Hasil penelitian menunjukkan adanya pengaruh positif antara sikap wajib pajak dan kepatuhan wajib pajak studi pada wajib pajak di Yogyakarta (Wijaya, 2019). Sikap wajib pajak secara signifikan 
mempengaruhi kepatuhan wajib pajak studi pada wajib pajak yang datang ke KPP Pratama Boyolali (Lestari, 2017). Sikap wajib pajak memiliki pengaruh positif dan signifikan terhadap kepatuhan wajib pajak pada pelaku ekonomi kreatif sub sektor fashion (Khotimah et al., 2020; Yustikasari, 2019). Sikap wajib pajak bertambah baik, maka dapat meningkatkan kepatuhan wajib pajak untuk melakukan pembayaran pajak.

Kesadaran perpajakan merupakan kerelaan kewajiban dan memberikan kontribusi kepada negara untuk menunjang pembangunan negara (Rahayu, 2010). Kesadaran tinggi dari wajib pajak dengan menganggap bahwa membayar pajak bukan suatu beban, tetapi suatu kewajiban dan tanggungjawab mereka sebagai warga negara sehingga mereka dapat membayar pajaknya dengan suka rela. Penelitian (Kamil, 2015) menunjukkan kesadaran wajib pajak memiliki efek positif dan signifikan pada kepatuhan wajib pajak individu Kantor Pajak di wilayah Jabodetabek dan Bandung. (Lestari, 2017; Wijaya, 2019). Hasil penelitian tentang kesadaran pajak terhadap kepatuhan wajib pajak menunjukkan pengaruh positif antara kesadaran pajak dan kepatuhan wajib pajak. Akan tetapi hasil penelitian (Kesaulya \& Pesireron, 2019; Khotimah et al., 2020) menunjukkan terdapat pengaruh yang tidak signifikan dari kesadaran wajib pajak terhadap kepatuhan wajib pajak.

Pengetahuan perpajakan adalah suatu keadaan di mana wajib pajak mengetahui dan memahami peraturan perpajakan, tata cara perpajakan, fungsi pajak, dan manfaat yang akan didapatkan (Ayuba et al., 2016; Yusnidar et al., 2015). Sehingga, pengetahuan pajak dapat menjadi sebuah informasi yang dapat digunakan wajib pajak untuk bertindak, mengambil keputusan, dan mengetahui kewajiban serta haknya dalam bidang perpajakan. (Pratama, 2018) menambahkan, pengetahuan perpajakan merupakan tingkat pengetahuan konsep pajak dasar yang terdiri dari aturan perpajakan dan pengetahuan keuangan yang perlu dipahami oleh wajib pajak dalam rangka memenuhi kewajiban perpajakan nya. Penelitian sebelumnya dari (Manual \& Xin, 2016; Newman et al., 2018; Susyanti \& Askandar, 2019) menyimpulkan bahwa ada hubungan antara pengetahuan pajak dan kepatuhan pajak. (Palil \& Rusyidi, 2013) peningkatan tingkat pengetahuan pajak dapat menyebabkan peningkatan tingkat kepatuhan pajak. (Kesaulya Juliana \& Pesireron, 2019; Mintje, 2016) pengetahuan perpajakan berpengaruh signifikan terhadap kepatuhan wajib pajak. (Cechovsky, 2018) Pengetahuan berhubungan positif dengan sikap kepatuhan pajak sukarela dan secara negatif terkait untuk sikap penghindaran pajak. Dengan adanya pengetahuan perpajakan dapat meningkatkan kemauan wajib pajak untuk membayar pajak karena wajib pajak yang telah memahami peraturan perpajakan akan berpikir untuk membayar pajak dari pada terkena sanksi (Suyono, 2016). Berlawanan dengan penelitian (Kamil, 2015) pengetahuan memiliki hubungan kepatuhan wajib pajak yang negatif dan signifikan, artinya WP memiliki tingkat pengetahuan tentang pajak yang baik ini sebenarnya mencari celah untuk menghindari kewajiban pajak.

Kepatuhan pajak menurut (Susyanti \& Dahlan, 2020) merupakan tindakan Wajib Pajak dalam pemenuhan kewajiban perpajakan nya sesuai dengan ketentuan peraturan perundang-undangan dan peraturan pelaksanaan perpajakan yang berlaku dalam suatu negara. Sedangkan menurut Keputusan Menteri Keuangan No. 544/KMK.04/2000 menyatakan bahwa: "Kepatuhan perpajakan adalah tindakan Wajib Pajak dalam pemenuhan kewajiban perpajakan nya sesuai dengan ketentuan peraturan perundang-undangan dan peraturan pelaksanaan perpajakan yang berlaku dalam suatu negara". Adapun beberapa indikator Kepatuhan wajib pajak yaitu sebagai berikut: 1) Mendaftarkan NPWP secara sukarela. 2) Mencatat keuangan usahanya secara rutin dan benar. 3) Mengisi, menghitung, dan melaporkan Surat pemberitahuan pajak dengan jujur, lengkap, dan benar sesuai dengan aturan yang berlaku. 4) Membayar Pajak secara sukarela sesuai dengan aturan dan tepat waktu. 5) Melaksanakan secara sadar penegakan hukum sanksi perpajakan.

\section{RUANG LINGKUP}

Kepatuhan pajak diartikan merupakan hal yang penting dalam melakukan pengumpulan pajak, karena kepatuhan merupakan ketaatan dalam menjalankan semua peraturan perpajakan. Ada dua macam kepatuhan pajak, yaitu: Kepatuhan Formal, keadaan dimana wajib pajak memenuhi kewajiban perpajakan nya secara formal sesuai dengan ketentuan dalam Undang-Undang Perpajakan. Dan Kepatuhan Material, keadaan dimana wajib pajak secara substantif atau hakikat memenuhi semua ketentuan material perpajakan, yakni sesuai isi dan jiwa Undang-Undang Perpajakan. Jika wajib pajak mengisi SPT dengan jujur, baik dan benar sesuai dengan ketentuan dalam UU Perpajakan, maka wajib pajak tersebut telah memenuhi kepatuhan material (tepat bayar).

Penelitian yang dilakukan merupakan pengukuran sikap wajib pajak, pengetahuan pajak dan kesadaran pajak. Kurangnya pengetahuan dan pemahaman pajak merupakan hambatan utama dalam memenuhi kewajiban perpajakan. Oleh karena itu perlu terus menumbuhkan kesadaran masyarakat dan kepatuhan wajib pajak untuk memenuhi kewajiban perpajakan sesuai dengan ketentuan yang berlaku.

Adapun permasalahan dalam penelitian, adalah: Bagaimana efek sikap wajib pajak terhadap kepatuhan pajak? ; Bagaimana efek kesadaran wajib pajak terhadap kepatuhan pajak?; dan Bagaimana efek pengetahuan perpajakan terhadap kepatuhan pajak?.

Hasil penelitian ini akan membantu memahami dan menganalisis efek sikap wajib pajak, pengetahuan perpajakan dan kesadaran wajib pajak terhadap kepatuhan pajak baik. 


\section{BAHAN DAN METODE}

Penelitian ini dapat diklasifikasikan sebagai penelitian deskriptif kuantitatif. Teknik pengumpulan data primer dilakukan dengan memberikan kuesioner kepada responden. Berdasarkan umpan balik kuesioner, dapat ditentukan (diukur) distribusi frekuensi untuk setiap variabel, sehingga dapat diketahui apakah niat baik untuk mematuhi pajak.

Populasi dalam penelitian ini adalah pelaku ekonomi kreatif di Malang Raya, Jawa Timur, Indonesia, secara eksklusif pada sub sektor fashion. Pemilihan subsektor fashion dan Malang sebagai focus penelitian, karena fashion berkontribusi cukup signifikan terhadap total pendapatan sektor pariwisata dan ekonomi kreatif, selain subsektor kuliner. Adanya pandemic covid-19 yang melanda pada saat penelitian menjadi kendala dalam pengumpulan kuesioner penelitian. Namun 100 pemilik subsektor fashion Malang Raya dapat berpartisipasi dalam penelitian ini. Menurut (Soekidjo, 2010) ukuran sampel sebagai berikut: (1) Ukuran yang layak digunakan dalam penelitian yaitu antara 30 sampai dengan 500; (2) Jika sampel terbagi dalam kategori, maka jumlah sampel setiap kategori minimal 50; (3) Jika dalam penelitian akan dilakukan analisis multivariate (korelasi atau regresi berganda), maka jumlah sampel minimal 10 kali dari jumlah variabel yang akan diteliti; (4) Pada penelitian eksperimen sederhana yang menggunakan kelompok eksperimen serta kelompok kontrol, maka jumlah sampel masing-masing antara 10 sampai dengan 20. Sebagai contoh, terdapat variabel penelitian sebanyak 4 (bebas dan terikat), maka jumlah sampel yaitu $20 \times 4=80$, mengacu pada teori dan kriteria sampel yang telah dijelaskan di atas, maka sampel yang digunakan dalam penelitian ini sebesar 100 responden untuk lebih memperoleh hasil yang baik (Soekidjo, 2010) Namun yang perlu diperhatikan adalah semakin besar jumlah sampel (semakin mendekati populasi) maka semakin kecil peluang kesalahan generalisasi dan sebaliknya, semakin kecil jumlah sampel (menjauhi jumlah populasi) maka semakin besar peluang kesalahan generalisasi .

Metode analis yang digunakan dalam penelitian dengan menggunakan software Smart PLS (Partial Least Square) untuk pengujian statistic inferensial. Dalam penelitian ini menggunakan pengujian model pengukuran pada construct reflektif pada jenjang second order construct (SOC). Pada gambar 1 untuk menganalisis penelitian ini digunakan pengujian hipotesis dengan PLS.

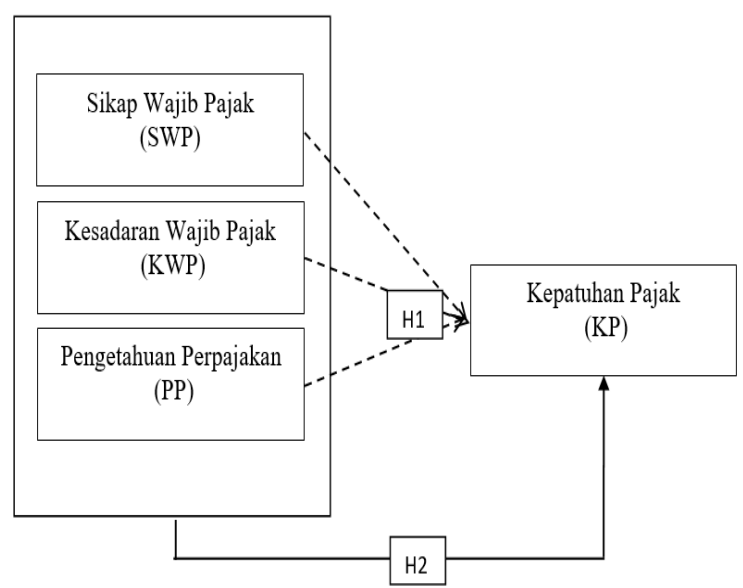

Gambar 1. Kerangka Konseptual

H1: sikap wajib pajak memiliki efek terhadap kepatuhan pajak. H2: kesadaran wajib pajak memiliki efek terhadap kepatuhan pajak. H3: pengetahuan perpajakan memiliki efek terhadap kepatuhan pajak.

\section{PEMBAHASAN}

Di dalam penelitian ini terdapat 4 variabel yaitu sikap wajib pajak, kesadaran wajib pajak, pengetahuan perpajakan dan kepatuhan pajak. Variabel bebas dalam penelitian ini adalah sikap wajib pajak, kesadaran wajib pajak dan pengetahuan perpajakan, sedangkan variabel terikat adalah kepatuhan pajak.

\subsection{Analis Deskriptif}

Responden pada penelitian ini adalah pelaku ekonomi kreatif sub sektor fashion yang usahanya masih aktif beroperasi sampai dengan waktu penelitian di tengah pandemi Covid-19 yang sedang terjadi. Perempuan adalah mayoritas responden dalam penelitian ini sebesar $63,5 \%$ dengan sebagian besar bisnis fashion digerakkan oleh kaum millennial usia 20-30 tahun sebanyak $60,2 \%$ dan untuk usia 31 - 40 tahun memiliki persentase yaitu sebesar $22,3 \%$. Mayoritas responden dalam penelitian ini mendapat maksimum $\mathrm{Rp}$ 1.000.000.000 untuk total pendapatan, artinya sektor ini berpotensi menjadi kekuatan yang ampuh untuk mendorong total pendapatan sektor pariwisata dan ekonomi kreatif.

\subsection{Validitas dan Reliabilitas}

Uji keabsahan kuesioner dilakukan dalam rangka menentukan keabsahan kuesioner. Secara statistik uji validitas menguji score individu dengan totalnya, jika korelasi diatas $0,5 \%$ maka indikator valid. Berdasar pada tabel 1 dapat terlihat masing-masing indikator memiliki nilai outer loading diatas $0,5 \%$, sehingga pernyataan dalam kuesioner indikator tersebut sah 
(valid) menjelaskan variabel kepatuhan pajak (KP), kesadaran wajib pajak (KWP), pengetahuan perpajakan (PP) dan sikap wajib pajak (SWP).

Tabel 1. Uji Validitas

\begin{tabular}{|l|l|l|l|l|}
\hline & SWP & KWP & PP & KP \\
\hline SWP & 0,746 & 0,738 & 0,697 & 0,714 \\
\hline KWP & & 0,720 & & 0,724 \\
\hline PP & & 0,771 & 0,743 & 0,770 \\
\hline KP & & & & 0,858 \\
\hline \multicolumn{5}{|c}{ Sumber: data diolah (2020) }
\end{tabular}

Uji reliabilitas menunjukkan uji konsistensi apakah responden menjawab secara konsisten/tidak berdasar tabel diatas indikator menjelaskan variabel kepatuhan pajak (KP), kesadaran wajib pajak (KWP), pengetahuan perpajakan (PP) dan sikap wajib pajak (SWP), dengan nilai Cronbach's Alpha, rho_A, berdasarkan tabel 2. reliabilitas Komposit diatas 0,7; sedangkan AVE diatas 0,5 sehingga pernyataan dalam kuesioner indikator tersebut reliabel menjelaskan kepatuhan pajak (KP), kesadaran wajib pajak (KWP), pengetahuan perpajakan (PP) dan sikap wajib pajak (SWP).

Tabel 2. Uji Reliabilitas

\begin{tabular}{|l|c|c|l|l|}
\hline & $\begin{array}{l}\text { Cronbac } \\
\text { h's } \\
\text { Alpha }\end{array}$ & rho A & $\begin{array}{l}\text { Composite } \\
\text { Reliability }\end{array}$ & $\begin{array}{l}\text { Average v } \\
\text { ariance } \\
\text { extracted } \\
\text { (AVE) }\end{array}$ \\
\hline SWP & 0.809 & 0,849 & 0,861 & 0,557 \\
\hline KWP & 0,809 & 0,888 & 0,840 & 0,518 \\
\hline PP & 0,784 & 0,858 & 0,854 & 0,552 \\
\hline KP & 0,910 & 0,913 & 0,933 & 0,737 \\
\hline
\end{tabular}

Sumber : data diolah (2020)

Adapun path coefficients dalam SmartPLS pada gambar 2, menjelaskan nilai koefisien pengaruh variabel sikap wajib pajak (SWP), kesadaran wajib pajak (KWP), pengetahuan perpajakan (PP) dan menjelaskan kepatuhan pajak (KP), adalah sebagai berikut:

$\mathrm{KP}=0,271 \mathrm{SWP}+0,188 \mathrm{KWP}+0,437 \mathrm{PP}$

Berdasarkan hasil pengujian dapat diketahui bahwa sikap wajib pajak (SWP) mampu menjelaskan kepatuhan pajak (KP). Demikian juga pada pengetahuan perpajakan (PP) dan kesadaran wajib pajak (KWP) mampu meningkatkan kepatuhan pajak (KP).

Dengan memperhatikan R square sebesar 0,656, hal ini menunjukkan kemampuan variabel sikap wajib pajak (SWP), kesadaran wajib pajak (KWP), dan pengetahuan perpajakan (PP) mampu menjelaskan kepatuhan pajak (KP), sebesar 65,6\%, sedangkan 34,4\% dijelaskan oleh variabel yang tidak diuji dalam model penelitian

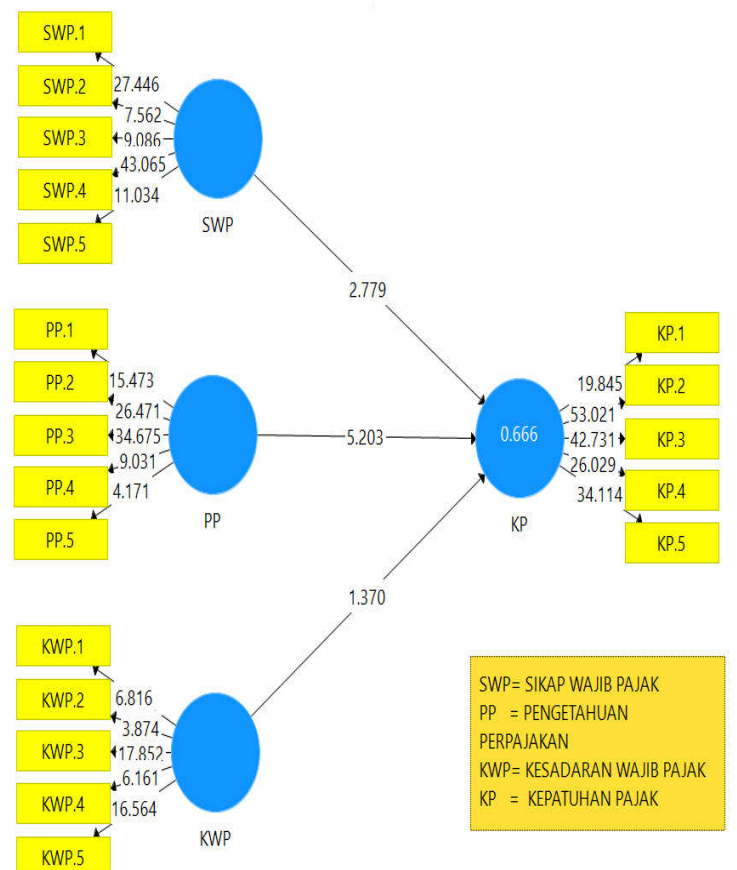

Gambar 2. Uji Pengaruh Langsung

Pengujian hipotesis/pengaruh langsung antara sikap wajib pajak, kesadaran wajib pajak, pengetahuan perpajakan dan kepatuhan pajak dapat dijelaskan pada tabel 3.

Tabel 3. Hasil Pengujian Hipotesis dalam inner model

\begin{tabular}{|l|l|l|l|l|}
\hline $\begin{array}{l}\text { Variabel } \\
\text { Bebas }\end{array}$ & $\begin{array}{l}\text { Variabel } \\
\text { Terikat }\end{array}$ & $\begin{array}{l}\text { Koefisien } \\
\text { Jalur }\end{array}$ & t-stat & p-value \\
\hline $\begin{array}{l}\text { Sikap Wajib } \\
\text { Pajak (SWP) }\end{array}$ & $\begin{array}{l}\text { Kepatuhan } \\
\text { Pajak (KP) }\end{array}$ & 0,271 & 2,779 & $\begin{array}{l}0,006 \\
\text { ns }\end{array}$ \\
\hline $\begin{array}{l}\text { Kesadaran } \\
\text { Wajib Pajak } \\
\text { (KWP) }\end{array}$ & $\begin{array}{l}\text { Kepatuhan } \\
\text { Pajak (KP) }\end{array}$ & 0,188 & 1,370 & $\begin{array}{l}0,171 \\
\text { ns }\end{array}$ \\
\hline $\begin{array}{l}\text { Pengetahuan } \\
\begin{array}{l}\text { Perpajakan } \\
\text { (PP) }\end{array}\end{array}$ & $\begin{array}{l}\text { Kepatuhan } \\
\text { Pajak (KP) }\end{array}$ & 0,437 & 5,203 & $0,000^{*}$ \\
\hline
\end{tabular}

Keterangan: tanda* menyatakan signifikan taraf 5\% Tanda ns menyatakan non signifikan

Berdasarkan pengujian hipotesis/pengaruh langsung diperoleh hasil uji:

H1 - sikap wajib pajak (SWP) berpengaruh langsung terhadap kepatuhan pajak (KP), dengan nilai t statistic sebesar 2,779 lebih besar dibanding t table sebesar 1,98, tidak signifikan dengan $\mathrm{P}$ values (nilai signifikansi) diatas 0,05

H2 - kesadaran wajib pajak (KWP) berpengaruh langsung terhadap kepatuhan pajak (KP), dengan nilai $t$ statistic sebesar 1,370 lebih kecil dibanding $t$ table sebesar 1,98, tidak signifikan dengan $\mathrm{P}$ values (nilai signifikansi) diatas 0,05 
H3 - pengetahuan pajak (PP) berpengaruh langsung terhadap kepatuhan pajak (KP), dengan nilai t statistic sebesar 5,203 lebih besar dibanding t table sebesar 1,98, signifikan dengan $\mathrm{P}$ values (nilai signifikansi) dibawah 0,05

\subsection{Analisis Efek Sikap Wajib Pajak, Kesadaran Wajib pajak, Pengetahuan Perpajakan terhadap Kepatuhan di Masa covid-19}

Problem kepatuhan pajak di beberapa negara banyak menjadi sorotan, terutama di negara berkembang seperti Indonesia (Besley \& Persson, 2014). Hasil penelitian ini mendukung kesimpulan penelitian sebelumnya terkait dengan sikap dan pengetahuan perpajakan, (Kesaulya Juliana \& Pesireron, 2019; Manual \& Xin, 2016; Mintje, 2016; Newman et al., 2018; Susyanti \& Askandar, 2019; Lestari, 2017; Wijaya, 2019; Yustikasari, 2019) yang menyatakan bahwa ada pengaruh positif antara sikap wajib pajak dan kepatuhan. Hal ini menunjukkan tidak ada perbedaan sikap UMKM yang mempertimbangkan kondisi keuangan dalam memenuhi kewajiban pajaknya dan risiko yang akan timbul akibat tidak membayar pajak di masa pandemi covid-19. Walaupun pemerintah dalam hal ini Direktorat Jenderal Pajak (DJP) juga memberikan stimulan untuk pelaku UMKM, dengan PMK no.86/PMK.03/2020, sebagai penghapusan PMK no 44/PMK.03/2020, aturan ini merupakan perubahan atas PMK No 23/PMK.03/2020 tentang insentif pajak untuk wajib pajak yang terkena dampak wabah virus corona.

Hasil penelitian ini mendukung penelitian tentang kesadaran pajak seperti dalam penelitian (Kesaulya Juliana \& Pesireron, 2019; Khotimah et al., 2020) menunjukkan terdapat pengaruh yang tidak signifikan dari kesadaran wajib pajak terhadap kepatuhan wajib pajak. Tidak ada perbedaan persepsi antara laki-laki dan perempuan dalam kesadaran untuk memenuhi kewajiban sebagai warga negara dalam hal pembayaran pajak. Meskipun mayoritas responden dalam penelitian ini memiliki persepsi yang relatif positif tentang pentingnya pengetahuan pajak dan sikap berdasar hasil kuesioner, mereka memiliki respons rendah dalam memahami kepatuhan pajak (Susyanti \& Askandar, 2019). Banyak pemilik ekonomi kreatif subsektor fashion (pada umumnya UMKM) yang masih bingung dalam menerapkan peraturan perpajakan; baik PP-23/2018 tentang PPh final, maupun PMK no.86/PMK.03/2020 terkait insentif perpajakan UMKM pada saat pandemi covid-19.

Hubungan antara pengetahuan pajak dan kepatuhan pajak, peningkatan tingkat pengetahuan pajak dapat menyebabkan peningkatan tingkat kepatuhan pajak (Cechovsky, 2018). Pengetahuan berhubungan positif dengan sikap kepatuhan pajak sukarela dan secara negatif terkait untuk sikap penghindaran pajak. Pengetahuan dan pemahaman terhadap tata cara perpajakan yaitu peniadaan layanan perpajakan secara langsung di kantor pajak di masa pandemic covid-19, digantikan dengan penyampaian surat pemberitahuan
(SPT) tahunan maupun masa melalui sarana pelaporan elektronik atau online (e-filing/e-form) di DJP Online, tidak menjadikan kepatuhan menjadi berkurang. Hal ini dibuktikan dengan dilakukannya pengisian SPT Tahunan secara mandiri dengan panduan yang ada di laman www.pajak.go.id atau pada akun media sosial resmi DJP, selain Wajib pajak juga melakukan konsultasi dengan account representative DJP melalui telepon, email, chat, dan komunikasi online lainnya. Sehingga, pengetahuan pajak dapat menjadi sebuah informasi yang dapat digunakan wajib pajak untuk bertindak untuk tetap patuh terhadap ketentuan yang dikeluarkan oleh Direktorat Jenderal Pajak (DJP).

Melalui PMK no.86/PMK.03/2020 seharusnya UMKM baik yang terkena dampak covid-19, maupun yang tidak secara langsung terkena dampak covid-19 dapat memanfaatkan insentif bebas $\mathrm{PPh}$ final mulai bulan April 2020 sampai dengan Desember 2020. Mereka hanya mengetahui pengetahuan pajak dan pemahaman pajak secara umum atau rata-rata. Hal ini dapat ditunjukkan baru sekitar 200 ribu UMKM pada bulan Juli 2020 yang sudah memanfaatkan insentif pajak di masa pandemi (pajakonline.com). Oleh karena itu, disarankan bahwa pendidikan perpajakan harus dimulai pada tahap awal edukasi tingkat seperti sekolah (Palil \& Rusyidi, 2013). Perlunya sosialisasi perpajakan untuk semua kalangan, baik dilakukan DJP secara langsung, maupun melalui kerja sama dengan Kementerian Koperasi dan UKM, Kementerian Pariwisata dan Ekonomi Kreatif. Harapannya, jika pemilik ekonomi kreatif subsektor fashion dan karyawan memiliki pengetahuan pajak yang memadai, akan ada minimalisasi ketidakpatuhan yang tidak disengaja.

\section{KESIMPULAN}

Hasil penelitian ini mendukung penelitian sebelumnya, terkait dengan sikap wajib pajak, kesadaran wajib pajak, dan pengetahuan perpajakan. Sikap wajib pajak di masa covid-19 tetap mempertimbangkan kondisi keuangan dan risiko jika tidak melakukan pembayaran pajak, sehingga pada umumnya UMKM masih bingung dalam menerapkan peraturan perpajakan, yaitu PMK no.86/PMK.03/2020 terkait insentif perpajakan UMKM pada saat pandemi covid-19. Kesadaran wajib pajak di masa covid-19 pun masih cukup tinggi dalam hal memenuhi kewajiban untuk membayar pajak, sedangkan pengetahuan perpajakan terkait penggunaan sarana pelaporan elektronik di masa pandemic covid-19 menunjukkan tetap populernya kepatuhan wajib pajak terhadap aturan yang berlaku.

Penelitian ini menyimpulkan bahwa ada efek yang secara langsung dari sikap wajib pajak, kesadaran wajib pajak dan pengetahuan pajak terhadap kepatuhan pajak, baik sebagian maupun bersamaan. Artinya untuk meningkatkan tingkat kepatuhan pajak, pemangku kepentingan harus meningkatkan pengetahuan dan mendorong sikap wajib pajak. Dengan adanya pengetahuan perpajakan dapat meningkatkan kemauan 
wajib pajak untuk membayar pajak karena wajib pajak yang telah memahami peraturan perpajakan akan berpikir untuk membayar pajak dari pada terkena sanksi. Menariknya, meskipun penelitian ini berhasil membuktikan efek antar variabel, hasil data sekunder menunjukkan bahwa banyak pelaku ekonomi kreatif subsektor fashion yang masih bingung dalam menerapkan peraturan perpajakan, PP-23/2018 maupun PMK no.86/PMK.03/2020 terkait insentif perpajakan UMKM.

\section{SARAN}

Penelitian ini memiliki keterbatasan pada sampel, dimana sikap wajib pajak, kesadaran wajib pajak, pengetahuan perpajakan tidak hanya pada industri kreatif sub sektor fashion. Saran bagi penelitian selanjutnya dapat menambah sampel pada sub sektor lainnya seperti kuliner, game dan aplikasi kriya sebagai subsektor yang merupakan keunggulan kompetitif daerah.

\section{DAFTAR PUSTAKA}

Aladejebi, D. O. 2018. Measuring Tax Compliance among Small and Medium Enterprises in Nigeria. International Journal of Accounting and Taxation, 6(2), 29-40. https://doi.org/10.15640/ijat.v6n2a4

Ayuba, A., Puteri, T., \& Safinaz, I. 2016. Factors, psychological factors and tax compliance: Evidence from nigerian SMEs. Management Journal, 20(December), 41-57.

Besley, T., \& Persson, T. 2014. Why do developing countries tax so little? Journal of Economic Perspectives, 28(4), 99-120. https://doi.org/10.1257/jep.28.4.99

Cechovsky, N. 2018. The importance of tax knowledge for tax compliance: A study on the tax literacy of vocational business students. European Conference on Educational Research (ECER), Vocational Education and Training Network (VETNET), September, $113-121$. https://doi.org/10.5281/zenodo.1319718

Ghozali, I. 2020. 25 GRAND THEORY. Teori Besar Ilmu Manajemen, Akuntansi dan Bisnis. Yoga Pratama.

Inasius, F. 2019. Factors Influencing SME Tax Compliance: Evidence from Indonesia. International Journal of Public Administration, 42(5), 367-379. https://doi.org/10.1080/01900692.2018.1464578

Kamil, N. I. 2015. The effect of taxpayer awareness, knowledge, tax penalties and tax authorities services on the tax complience: Survey on the individual taxpayer at Jabodetabek \& Bandung). Research Journal of Finance and AccountingOnline), 6(2), 104-112.

https://www.iiste.org/Journals/index.php/RJFA/articl e/view/19180/19738

Kesaulya J., \& Pesireron, S. 2019. Pengaruh Pengetahuan Perpajakan, Sanksi Pajak Dan Kesadaran Wajib Pajak Terhadap Kepatuhan Wajib
Pajak Dalam Membayar Pajak (Study Empiris Pada Umkm Di Kota Ambon). 8(1), 160-168.

Khotimah, I. M. K., Susyanti, J., \& Mustapita, A. F. 2020. Pengaruh Sikap Wajib Pajak, Kesadaran Wajib Pajak, Pengetahuan Perpajakan, Dan Sanksi Perpajakan Terhadap Kepatuhan Wajib Pajak Orang Pribadi Pada Pelaku Ekonomi Kreatif Sub Sektor Fashion Di Kota Batu. Jurnal Riset Manajemen, 116.

Kwok, B. Y. S., \& Yip, R. W. Y. 2018. Is Tax Education Good or Evil for Boosting Tax Compliance? Evidence from Hong Kong. Asian Economic Journal, 32(4), 359-386.

Lestari, T., \& Wicaksono, M. (2017). Effect of Awareness, Knowledge and Attitude of Taxpayers Tax Compliance for Taxpayers in Tax Service Office Boyolali. International Journal of Economics, Business and Accounting Research, 1(1).

Manual, V., \& Xin, A. Z. 2016. Impact of Tax Knowledge, Tax Compliance Cost, Tax Deterrent Tax Measures towards Tax Compliance Behavior: A survey on Self-Employed Taxpayers in West Malaysia. Electronic Journal of Business and Management, 1(1), 56-70.

Mintje, M. S. 2016. Pengaruh Sikap, Kesadaran Dan Pengetahuan Terhadap Kepatuhan Wajib Pajak Orang Pribadi Pemilik UMKM Dalam Memiliki NPWP (Studi pada Wajib Pajak Orang Pribadi Pemilik UMKM yang Terdaftar di KPP Pratama Manado). Jurnal Riset Ekonomi, Manajemen, Bisnis Dan Akuntansi, 4(1), 1031-1043.

Newman, W., Mwandambira, N., Charity, M., \& Ongayi, W. 2018. Literature review on the impact of tax knowledge on tax compliance among small medium enterprises in a developing country. Journal of Legal, Ethical and Regulatory Issues, 22(4), 1-15.

Palil, M. R., \& Rusyidi, M. A. 2013. The Perception of Tax Payers on Tax Knowledge and Tax Education with Level of Tax Compliance: A Study the Influences of Religiosity. ASEAN Journal of Economics, Management and Accounting, 1(1), 118129.

Pratama, A. 2018 Individual Taxpayer Characteristics and Taxpayer Knowledge: Exploratory Survey on Individual Taxpayers in Bandung City, Indonesia. Review of Integrative Business and Economics ResearchOnlineCDROM, 7(1), 2304-1013.

Rahayu, S. K. 2010. Perpajakan Indonesia. Salemba Empat.

Sabil, S., Lestiningsih, A. S., \& Pujiwidodo, D. 2018. Pengaruh E-Spt Pajak Penghasilan Dan Pemahaman Pajak Terhadap Kepatuhan Wajib Pajak. Jurnal SIKAP (Sistem Informasi, Keuangan, Auditing Dan Perpajakan), 2(2), https://doi.org/10.32897/sikap.v2i2.67

Sani, A., \& Habibie, A. 2019. Pengaruh Moral Wajib Pajak, Sikap Wajib Pajak dan Norma Subjektif terhadap Kepatuhan Pajak melalui Pemahaman 
Akuntansi. Jurnal Ilman: Jurnal Ilmu Manajemen, 5(2).

Soekidjo, N. 2010. Metode Penelitian Kuantitatif Kualitatif dan R\&D. Bandung, CV Alfabeta.

Susyanti, J. 2014. Problems Identification of Creative Economy Business Actors of Tourism Sector in Malang City in Effort To Meet Tax Obligations. 14(February), https://doi.org/10.13140/RG.2.2.27937.51048

Susyanti, J. \&, \& Askandar, N. S. 2019. Why Is Tax Knowledge and Tax Understanding Important? JEMA: Jurnal Ilmiah Bidang Akuntansi Dan Manajemen, 16(2), 187. https://doi.org/10.31106/jema.v16i2.2711

Susyanti, J., \& Dahlan, A. 2020. Perpajakan untuk Akademisi dan Pelaku Usaha (E. D. media (Kelompok I. Publishing) (ed.); 1st ed.). Empat Dua media (Kelompok Intrans Publishing).

Suyono, N. A. 2016. Faktor-faktor yang Mempengaruhi Kepatuhan Membayar Pajak di Kantor Pelayanan Pajak Wonosobo. Ppkm I (2016) 1-10 Fakultas Ekonomi Universitas Sains Al Qur'an Wonosobo, 110.

Wijaya, S. 2019. Taxpayer Attitude on the Elimination of Tax Sanction and Taxation Awareness Toward Taxpayer Compliance in Yogyakarta. Jurnal
Manajemen Indonesia, $19(1), \quad 71$. https://doi.org/10.25124/jmi.v19i1.1986

Yusnidar, J., Sunarti, \& Prasetya, A. 2015. Pengaruh Faktor-Faktor yang Mempengaruhi Kepatuhan Wajib Pajak dalam Melakukan Pembayaran Pajak Bumi dan Bangunan Perdesaan dan Perkotaan (Studi pada Wajib Pajak PBB-P2 Kecamatan Jombang Kabupaten Jombang). Jurnal Perpajakan (JEJAK), 1(1), 1-10.

Yustikasari, M. Y. 2019 Pengaruh Sikap Wajib Pajak, Kesadaran Wajib Pajak, Dan Pengetahuan Perpajakan Terhadap Kepatuhan Wajib Pajak Orang Pribadi Pada Pelaku Ekonomi Kreatif Sub Sektor Fashion Di Kota Batu. E-Jurnal Riset Manajemen.

\section{UCAPAN TERIMA KASIH}

Terima kasih kepada Kementerian Riset dan Teknologi/ Badan Riset dan Inovasi Nasional sesuai dengan Surat Perjanjian No: 018/SP2H/AMD/LT/MULTI/L7/2020; 206/G164/U.LPPM/K/B.07/VIII/2020 Skim Penelitian Terapan Unggulan Perguruan Tinggi (PTUPT). 